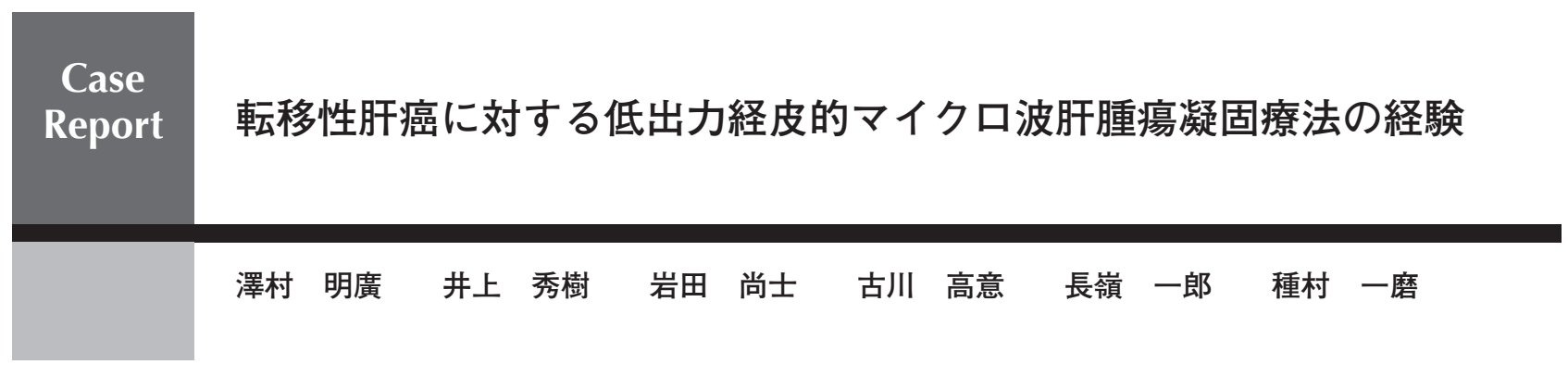

\title{
A case of metastatic liver tumor treated with percutaneous low output microwave tissue coagulation therapy using a new needle electrode $1 \mathrm{~mm}$ in diameter
}

Akihiro Sawamura, Hideki Inoue, Takashi Iwata, Takaoki Furukawa, Ichirou Nagamine and Kazuma Shimura

\begin{abstract}
The case is a 72 -year-old-male who was treated with percutaneous transhepatic low output microwave tissue coagulation therapy (PLMCT) using a new needle electrode $1 \mathrm{~mm}$ in diameter for metastatic liver tumor in touch with liver surface and the intestine. This needle electrode is more useful than an old type $16 \mathrm{G}$ needle electrode in strength and the point that coagulated tissue is hard to adherent to the electrode. PLMCT was performed at the output of 40 watt for 90 seconds at a time. Tumor $1.7 \mathrm{~cm}$ in diameter was completely coagulated by irradiation 2 times and the intestine in touch with the liver surface was preserved judged by enhanced CT.

The results suggested that PLMCT using a new electrode $1 \mathrm{~mm}$ in diameter is a useful therapy even for small solitary liver tumor in touch with liver surface.
\end{abstract}

Key words: metastatic liver tumor, PLMCT, needle electrode

Accepted on Mar. 13, 2008

医療法人社団曙会シムラ病院外科７７30-0841 広島県広島市中区舟入町3-13

Department of Surgery, Shimura Hospital

Address: 3-13, Funairi-cho, Naka-ku, Hiroshima-city, Hiroshima, 730-0841, Japan 


\section{緒 言}

細径の深部電極を用いた低出力マイクロ波肝腫瘍凝固 療法 (PLMCT) の有用性について報告してきた ${ }^{12)}$. 今 回は $1 \mathrm{~mm}$ 径のパーキュプロ ${ }^{\circledR} \mathrm{DP}$ 用いて低出力による 経皮的PLMCTを転移性肝癌の 1 例に施行し，良好な結 果を得たので報告する。

\section{I . 症例}

患 者: 72歳, 男性.

主 訴：特記すべきことなし.

既往歴：高血圧症, 糖尿病, 肝硬変, 13 年前, 肝内胆 管癌にて肝左葉切除術.

家族歴：特記すべきことなし.

現病歴 : 肝硬変のフォローアップの腹部エコーにて肝 S5に腫瘤を指摘され, 当院紹介され受診. 精查, 加療の ため, 当院入院となった.

入院時現症: 体格中等度, 眼球結膜に黄㾝を認めず, 腹部は平坦, 軟であった。 上腹部にはMercedes markの 手術創瘏痕を認めた。

入院時検查所見：血液生化学検査では, HCV-Ab (+) で, 肝機能は肝硬変パターンであった，血糖は306mg/ dLと高值を示し，AFPは正常範囲内であったが，CEA は6.7ng/mLと軽度の高值を示した。出血時間は正常範 囲内であった（Table 1).

画像所見：腹部エコーでは，肝表面は凹凸不整で, edgeはdullであり, 腫瘤はS5の肝床部肝表面直下に存在 し, 比較的境界明瞭な径 $1.7 \mathrm{~cm}$ の低エコーパターンを示 した.内部は顆粒状の低エコーレベルを示した。 また, 前回手術の影響によるものと思われるが，消化管が肝に 接しているのがわかる (Fig. 1a)。造影CT像では, S5の 肝床部肝表面直下に径約 $2.0 \mathrm{~cm}$ の淡く造影される腫瘍と して描出され, 肝外からの腫瘍へのフィーダーが描出さ

\section{Table 1 Laboratory data on admission}

\begin{tabular}{llllll|l}
$\mathrm{Hb}$ & $14.0 \mathrm{~g} / \mathrm{dL}$ & GOT & $58 \mathrm{U} / \mathrm{L}$ & AFP & $4.4 \mathrm{ng} / \mathrm{mL}$ \\
$\mathrm{Plt}$ & $13.0 \times 10^{4} / \mathrm{MCL}$ & GPT & $40 \mathrm{U} / \mathrm{L}$ & CEA & $6.7 \mathrm{ng} / \mathrm{mL}$ \\
$\mathrm{T}-\mathrm{Bil}$ & $1.0 \mathrm{mg} / \mathrm{dL}$ & ChE & $3,286 \mathrm{U} / \mathrm{L}$ & & \\
$\mathrm{TP}$ & $7.8 \mathrm{~g} / \mathrm{dL}$ & T-Cho & $144 \mathrm{mg} / \mathrm{dL}$ & & \\
$\mathrm{ALB}$ & $4.3 \mathrm{~g} / \mathrm{dL}$ & BUN & $12.0 \mathrm{mg} / \mathrm{dL}$ & & \\
& & BS & $306 \mathrm{mg} / \mathrm{dL}$ & & \\
HCV-Ab & $(+)$ & & & & \\
\hline
\end{tabular}

れた．腹部エコーと同様に消化管が肝に接しているのが わかる (Fig. 2a).

入院後経過: C型肝硬変合併の肝細胞癌を疑い, 本 人・家族へのインフォームド・コンセントの結果, PLMCTが選択された. PLMCTの方法としては，まず， 局所麻酔下に $16 \mathrm{G}$ のクイックカットにて経皮的に肝生検 を行い, 続けてクイックカットの外筒より $1 \mathrm{~mm}$ 径のパ ーキュプロ ${ }^{\circledR} \mathrm{DP}$ を挿入， 1 回の焼灼は $40 \mathrm{~W} ， 90$ 秒で計 2 回の焼灼を行った. 電極は肋間より, グリソンや, 肝床 部に直角になるよう刺入した。 焼灼中には, 凝固範囲が 消化管に及ばないようにエコーにて注意深く観察しつつ 焼灼した. PLMCT直後の腹部エコーでは, 矢印で示す ように肝外からの脈管が高エコーに変化していた (Fig. 1b). PLMCT後第 4 病日の造影CTでは, 腫瘍はよ く凝固され, 肝外からの脈管は造影されなかった. 腹部 エコーで観察された脈管の高エコー像は, 肝外からの腫 瘍へのフィーダーが凝固されたものと判断された. また, 消化管への影響はないように思われた（Fig. 2b).

術後 4 時間後よりトイレ歩行を許可し, トラブルは認 めなかった. 術後の鎮痛剂使用も 1 回だけで, 以後疼痛 は認めなかった. 4 日後の造影CTで十分な凝固が得ら れたため, 糖尿病のコントロール後軽快退院, それは PLMCT後第 8 病日であった. 以後, 外来でフォロー アップしているが, 23 月後現在再発を認めていない. なお病理結果では, 間質の反応を伴ってatypical tubules のinvasive growthより tubular adenocarcinomaの存在 を認め, cholangiocellular carcinomaの再発が示唆され た。

\section{II. 考察}

過去巻において18Gの細径電極を用いたPLMCTの有 用性について報告してきた ${ }^{1)-5)}$. 今回我々は, $1 \mathrm{~mm}$ 径 のパーキュプロ ${ }^{\circledR} \mathrm{DP}$ を使用し, 肝表面直下の腫瘍に対し てPLMCTを施行した.このパーキュプロ ${ }^{\circledR} \mathrm{DP}$ 電極は, 電極先端 $6 \mathrm{~cm}$ の部位にフッ素樹脂系塗料をコーティン グしたことにより，凝固組織の焦げ付きが少なくなり， 常時軸回転操作や解離操作が不要となった. さらに, 以 前使用していた $18 \mathrm{G}$ の電極に比較して, 内部電極と外部 電極の接続部の強度が向上した点で, 改善が認められた。 焼灼範囲は, 旧電極との間で差は認められなかった，細 径の深部用電極を使用し, 低出力にすることで, 局所麻 


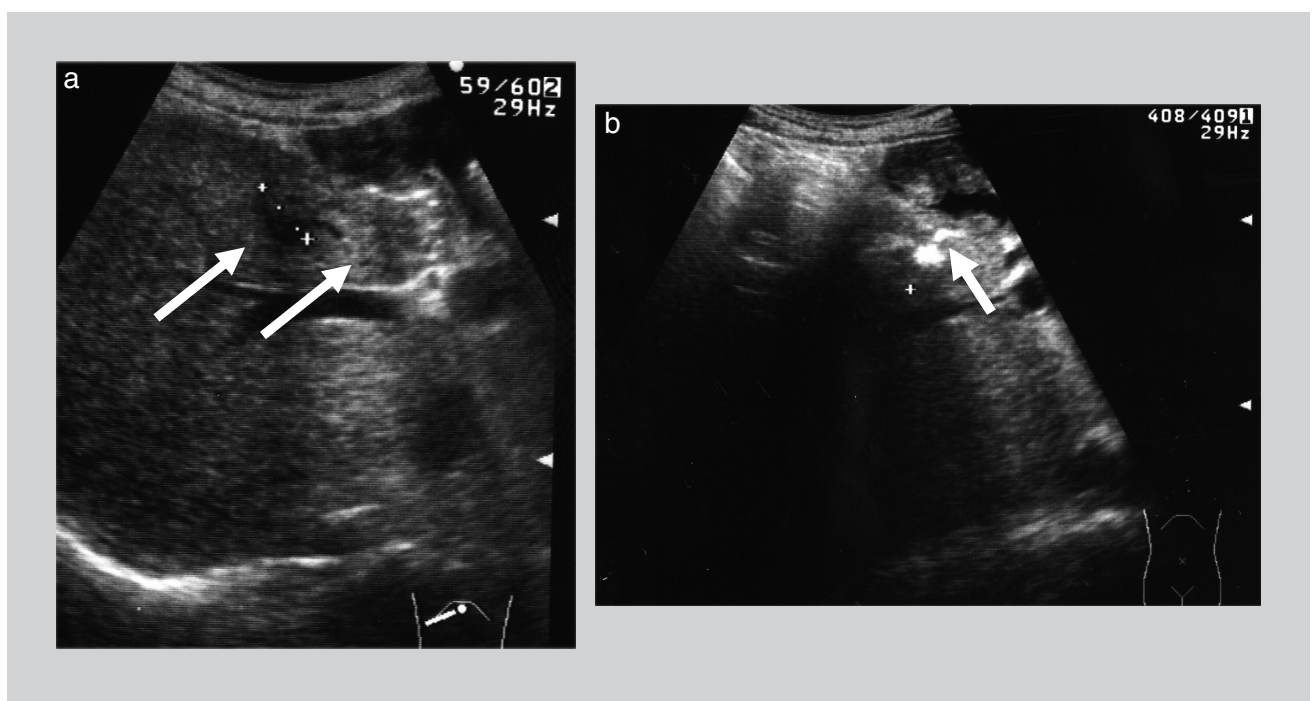

\section{Figure 1}

Ultrasonography just before PLMCT showed a solid tumor in touch with inferior surface of the liver and the intestine (arrows), $1.7 \times 1.7 \mathrm{~cm}$ in size in the anterior hepatic segment (a). Just after PLMCT, feeding artery entering the tumor out of the liver (arrow) was changed to high echoic level (b).

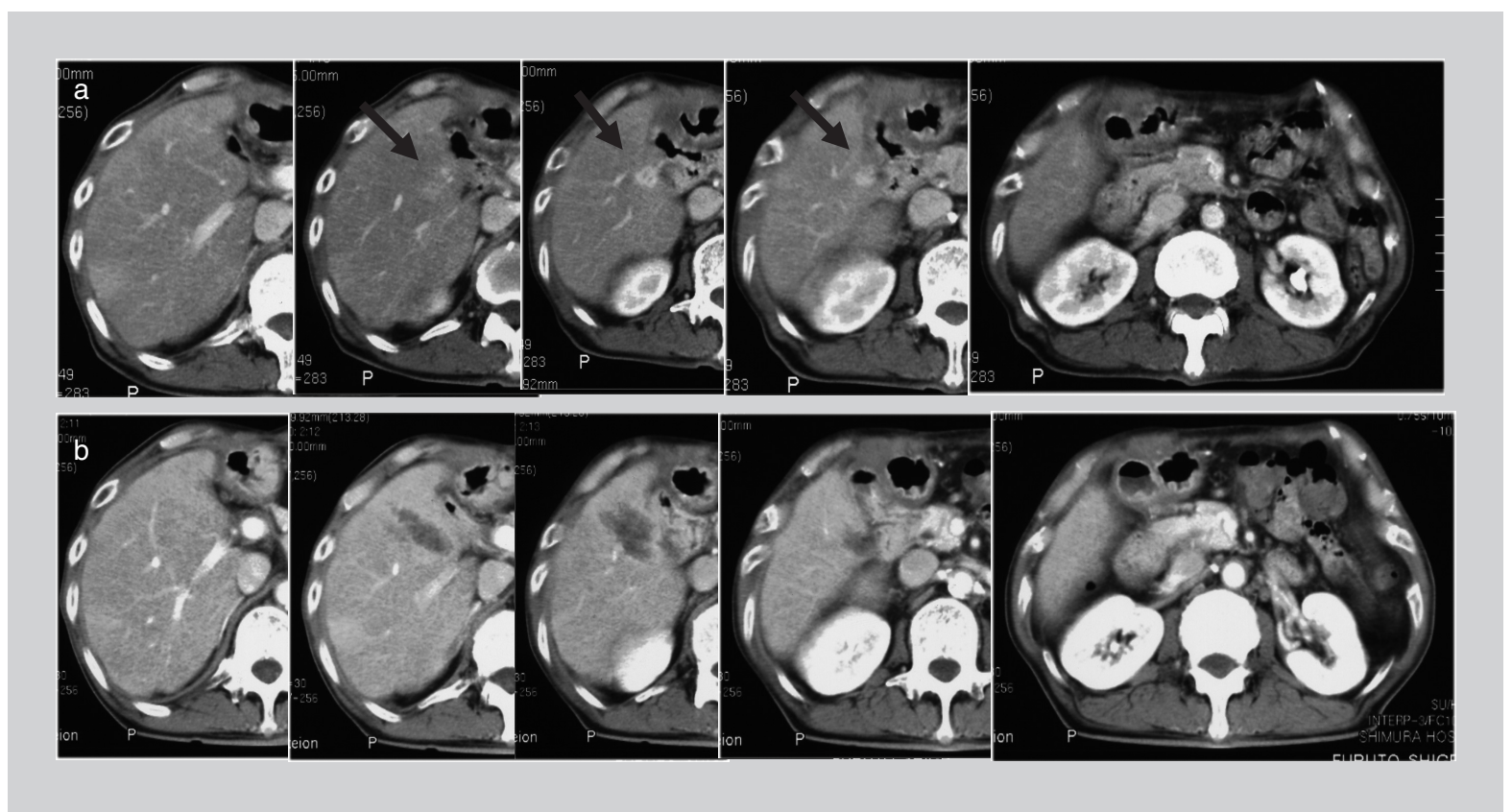

Figure 2

Enhanced abdominal CT before PLMCT showed a solid tumor in touch with inferior surface of the liver and the intestine (arrows), $1.7 \times 1.7 \mathrm{~cm}$ in size in the anterior hepatic segment and feeding artery entering the tumor out of the liver (a). Four days after PLMCT, the tumor was completely coagulated, the feeding artery entering the tumor out of the liver was not enhanced and the intestine in touch with the liver surface was preserved (b). 
酔下での凝固が可能である.ささらに, 低出力であるため, 焼灼中にバブリングが発生せず白色に変化することによ り，燒灼範囲をエコーで観察することができるなどの利 点があげられる，低出力であるため, 凝固範囲が狭く 2

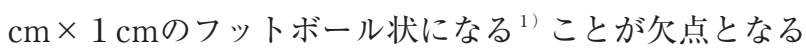
が，逆に腫瘍がグリソンや肝表面に接している場合など には適していると思われる ${ }^{6)}$ ，なぜならば，電極先端ま でが凝固範囲となるため, グリソンに直角に当てること で，また，焼灼中に凝固範囲が確認できるので，温存し たい部位を避けて凝固することが可能になる，今回の症 例においても，電極を肝表面に直角に当てることで，肝 床部に接した腸管を損傷することなく凝固されていたこ とが. 術後の造影CTにて確認されている.さらに, 細径 の深部用電極は, 肝細胞癌に対するメインでの使用だけ でなく, RFAや太いマイクロ波深部電極と併用し, グリ ソン周囲の凝固や, 肝生検時の止血に有用であると思わ れる. 我々が考案したPLMCTは低出力でありながら，

(1)高出力と同等の凝固範囲が得られること,
(2)細径の電極を使用することで，局所麻醉による除痛 ができること，

(3)バブリングが起こらず焼灼中にエコーで観察可能な こと,

(4)術後の鎮痛剂の使用もほとんど必要ないこと, 以上のようなことから, 非常に低侵襲な方法であると考 えられ，患者のQOLも損なうこともなく，有用な手技で あると思われる。

\footnotetext{
結 語

今回, 我々は $1 \mathrm{~mm}$ 径のパーキュプロ ${ }^{\circledR} \mathrm{DP}$ 用いた PLMCTを肝硬変合併胆管細胞癌の肝表面直下への転移 症例に行い, 十分な凝固が得られた. さらに, 肝床部に 接する腸管を温存することも可能であった，本療法は低 侵襲であり，局所コントロールには有用であると思われ る.
}

\section{References}

1) 澤村明廣, 吉本晃宏, 武田晋平, 青儀健二郎, 船越真人, 平井敏弘, 峠 哲哉: 新しい電極を用いた経皮的マイクロ波腫湟凝固療法の基礎的検討. J Microwave Surg $12: 9-12,1994$

2）澤村明廣, 青儀健二郎, 吉本晃宏, 峠 哲哉：Bedside treatmentとしての経皮的マイクロ波腫瘍凝固療法. J Microwave Surg 14：43-48, 1996

3）吉本晃宏, 澤村明廣, 青儀健二郎, 峠 哲哉, 国安弘基, 田原栄一：マイクロ波凝固による病理組織学的変化と細胞活性. J Microwave Surg 14： 17-22, 1996

4）澤村明廣, 宮原栄治, 青儀健二郎, 檜原 淳, 野間浩介, 南 一仁, 吉田和弘, 山口佳之, 峠 哲哉：孤立性肝癌に対する局所麻酔下経皮的マイク 口波腫瘍凝固療法の検討. 癌と化療 $24: 1643-1646,1997$

5 ）澤村明廣，南 一仁，大田耕司，峠 哲哉：低出力マイクロ波による局麻下経皮的肝腫㷚凝固療法の検討. J Microwave Surg 18：23-26, 2000

6 ）澤村明廣, 井上秀樹, 岩田尚士, 長嶺一郎, 種村一磨： $1 \mathrm{~mm}$ 径パーキュプロ ${ }^{\circledR} \mathrm{DP}$ 用いた低出力経皮的マイクロ波肝腫瘍凝固療法の使用経験. J Microwave Surg 25 : 115-118, 2007 